\title{
Financial Performance of Banks in Botswana
}

\author{
Hassan Kablay*, Victor Gumbo \\ Department of Mathematics, University of Botswana, Gaborone, Botswana \\ Email: ^hassankablay@gmail.com
}

How to cite this paper: Kablay, $H$. and Gumbo, V. (2021) Financial Performance of Banks in Botswana. Journal of Mathematical Finance, 11, 386-397. https://doi.org/10.4236/jmf.2021.113022

Received: May 17, 2021

Accepted: July 24, 2021

Published: July 27, 2021

Copyright $\odot 2021$ by author(s) and Scientific Research Publishing Inc. This work is licensed under the Creative Commons Attribution International License (CC BY 4.0).

http://creativecommons.org/licenses/by/4.0/

\begin{abstract}
Banks play a vital role in the financial system of any country. This study aims to examine the financial performance of eleven banks in Botswana for the period 2015 to 2019 using Return on Assets (ROA), Return on Equity (ROE), and Cost-to-Income (C_I) ratio as the financial measures (dependent variables), and fifteen other ratios (independent variables) as the drivers of financial performance. ROA was used to measure the internal-based performance of banks, ROE was used to study and understand the amount of a bank's income that is returned as shareholders' equity, and C_I ratio was used to study and understand the productivity and efficiency of banks. The data were obtained from the financial statements and annual reports of the banks under study. The study employed correlation and multiple regression analysis and it was established that the most significant driver of a bank's ROA and ROE is the "interest income on loans over average total assets" (II_AVG_TA) ratio. However, this ratio was the least significant driver of the C_I ratio. The most significant driver of the $C_{-} I$ ratio was found to be the "interest expense over assets" (IE_A) ratio.
\end{abstract}

\section{Keywords}

Financial Performance, Multiple Regression Analysis, ROA, ROE, C_I

\section{Introduction}

"The heart of any financial system lies in the banking sector" (Munangi and Sibindi, 2020) [1]. Banks play a vital role in the economic development of nations as they are at the center of global financial system. "Banks are the largest financial intermediaries in our economy" (Mishkin, 2013) [2]. They channel funds from depositors to investors and need to be profitable in order to carry out their sustainable intermediation function (Ongore and Kusa, 2013) [3]. Bank performance is important to individual consumers of bank deposit and loan services, employees, government regulators, as well as to the entire economy (Qamruz- 
zaman, 2014) [4]. Several studies have indicated the importance of financial performance of banks and this can be measured using a combination of comparative financial ratio analysis (Aymen, 2013) [5]. Furthermore, financial performance is important in a competitive financial market as it provides a signal to depositors (investors) to decide whether to invest or withdraw their capital from the bank (Aymen, 2013) [5]. For these reasons, the role of banks has come under greater scrutiny ever since the global financial crises of 2008 and the 1929 Great Depression, and the finanial performance of banks has become of great interest to academic research. Banks in Botswana have continued to support economic growth and activity (Gabaraane, 2018) [6]. A bank's performance is its capacity to generate sustainable profitability (El Mehdi, 2018) [7]. Poor bank performance can lead to bank failure, which can then have a ripple effect on the economy. Banks are expected to be stable and financially sound, they are key to economic growth and play a major role in the utilisation of the country's resources, therefore it is imperative that the financial performance of banks is evaluated.

Botswana has a total of 12 banks, 9 of these are commercial banks and 3 are statutory banks. 4 of the banks are listed on the Botswana Stock Exchange. This study focused on only 11 banks due to the unavailibility of deposits by the National Development Bank (NDB). As at the end of 2019, the 11 banks had a total of 151 branches and sub-branches, and 542 automated teller machines (ATMs) (BOB Banking Supervision Annual Report, 2019) [8]. In 2019, profitability ratios for banks in Botswana remained strong and in line with international norms for banks of comparable size. The Return on Equity (ROE) increased from $16.1 \%$ in 2018 to $16.2 \%$ in 2019 while the Return on Average Assets (ROAA) was constant at 1.9\% (BOB Banking Supervision Annual Report, 2019) [8].

All activities and strategies are designed to realise the objective of profit, which is the primary goal of all commercial banks (Rawan, 2019) [9]. In this study, internal factors, being the financial ratios were used to measure the financial performance of banks in Botswana. ROA was used as a profitability measure to evaluate the internal-based performance of banks, whilst ROE was utilised to understand the amount of a bank's income that is returned as shareholders equity. Finally, the C_I ratio was used to study and understand the productivity and efficiency of the banks.

\section{Literature Review}

Nataraga et al. (2018) [10] carried out a study on the 3 major private sector banks that are listed on the National Stock Exchange (NSE) and Bombay Stock Exchange (BSE). Return on Assets (ROA), Tobin's Q model and Return on Equity (ROE) were the three indicators used to measure the financial performance of the selected banks. The data used in the study ranged from 2006 to 2007 and the study revealed that bank size, asset management, operational efficiency and debt ratio had influence on the financial performance of private commercial banks. 
In a study by Aymen (2013) [5], the relationship between capital (represented by equity/capital) and financial performance (represented by ROA, ROE, NIM) was investigated and it was found out that financial performance and capital have a positve relationship.

Antwi (2019) [11] studied the relationship between capital adequacy, cost-toincome ratio and performance of banks in Ghana for the period 2013 to 2018 and one of the major findings was that cost-to-income ratio has a negative statistically significant relationship with ROA and ROE. In another study of banks in Ghana, Nyarko (2018) [12] carried out a study on the relationship between non-performing loans and profitability of the four major banks in the country. The findings indicated that non-performing loans ratio negatively affected profitability.

Abduh and Alias (2014) [13] carried out a study of the factors that influence the Islamic banking performance in Malaysia for the period 2006 to 2010. The independent variables used were loan-loss provision to total assets, net loans to total assets, total overhead cost to total assets, shareholders equity ratio, bank size GDP and inflation. Using Pooled OLS, their study revealed that loan loss provision to total assets, total overhead cost to total assets and inflation were the significant variables that affected the Malaysian Islamic banking performance in that study period.

The impact of credit risk on the financial performance of 18 South African banks for the period 2008 to 2018 was studied by Munangi and Sibindi (2020) [1], and some of their major findings were that credit risk is negatively related to financial perfomance and capital adequacy was positevly related to financial performance. In addition to that, they found out that bank leverage and financial performance were negatively related.

Kablay and Gumbo (2021) [14] studied the drivers of bank distress in Botswana for the period 2015-2019 and they found out that ROE and NPL ratio are the best predictors of bank distress. Moreover, in their study they established that ROE had a negative and significant effect on financial distress of banks in Botswana.

Credit granted by banks needs to be monitored and collected without difficulty. The LLP_TL ratio has a negative effect on bank revenues which in turn can decrease profitabilty (Demirhan, 2013) [15].

A majority of the past research shows that ROA, ROE and C_I ratio are very important and widely used measures in the study of financial performance of banks. This is in line with The Economic Central Bank (2010) [16] which states that the aforementioned ratios are the most widely used traditional performance measures.

\section{Definition of Variables}

In multiple regression, the aim is to predict the dependent variable $Y_{i}$ (score).

In this study, the dependent variables $Y_{i}$ are: 
- $Y_{1}=$ ROA (Return on Assets) $=$ Net profit after taxes/Assets: This is a basic measure of bank profitability (Mishkin, 2013) [2]. It illustrates how well management is using the bank's total assets to generate more income (profit). The higher the return, the more efficient management is in utilizing it's asset base (Nataraja et al., 2018) [10].

- $Y_{2}=\operatorname{ROE}$ (Return on Equity) $=$ Net profit after taxes/Equity Capital: This is another basic measure of bank profitability which indicates how much the bank is earning on their equity investment (Mishkin, 2013) [2]. ROE measures how a bank's manageteam effectively manages the capital that shareholders entrust to it. A high ROE is expected for high growth of banks (Nataraja et al., 2018) [10].

- $Y_{3}=$ C_I (Cost-to-income ratio) = Operating Expenses/Operating Income: The cost-to-income ratio is a key financial measure (Hussain, 2014) [17]. This ratio measures how costs are changing in comparison to income. The lower the ratio the more efficient the bank.

The independent variables $X_{i}$ are:

- $X_{1}=$ NPL_Ratio (Non Performing Loans Ratio) = Non Performing Loans/ Gross Advances

- $X_{2}=$ A_E (Assets to Equity Ratio) $=$ Assets/Equity

- $X_{3}=$ LLP_TL (Loan Loss Provision to Total Loans Ratio)

- $X_{4}=$ II_IE (Interest Income to Interest Expense Ratio) = Interest Income/ Interest Expense

- $X_{5}=$ LA_TD (Liquid Assets to Deposit Ratio) = Liquid Assets/Deposits

- $X_{6}=$ NET_II_TI (Net Interest Income to Total Income ) = Net Interest Income/Total Income

- $X_{7}=$ NII_TI (Non-Interest Income to Total Income) $=$ Non-Interest Income/Total Income

- $X_{8}=$ NIM (Net Interest Margin) $=$ Net-Interest Income/Average Assets

- $X_{9}=$ I_A (Total Income to Average Assets Ratio) = Total Income/Average Assets

- $X_{10}=$ CA_TA (Circulating Assets to Total Assets Ratio) = Circulating Assets/Total Assets

- $X_{11}=$ TL_TA $($ Total Liabilities to Total Assets Ratio $)=$ Total Liabilities/Total Assets

- $X_{12}=$ CAR $($ Capital Adequay Ratio $)=($ Tier 1 Capital + Tier 2 Capital $) /$ Risk Weighted Assets

- $X_{13}=$ IE_A = Interest Expense/Assets

- $X_{14}=$ II_AVG_TA = Interest Income on Loans/Average Total Assets

- $X_{15}=$ LDR (Loans to Deposit Ratio) $=$ Loans/Deposits

\section{Objectives}

The main aim of the study is to analyse the financial performance of banks in Botswana. The researchers sought to accomplish this through: 
- Measuring the internal-based perfomance of banks by using return on assets (ROA).

- Studying and understanding the amount of a bank's income that is returned as shareholders equity (ROE),

- Studying and understanding the productivity and efficiency of banks using cost-to-income ratio (C_I).

\section{The Modelling Approach}

In this study, due to the unavailability of deposits by the National Development Bank (NDB), we only consider 11 banks in Botswana. These have a total of 151 branches and sub-branches, and 542 automated teller machines (ATMs) as at the end of 2019. Data was collected from the annual reports and financial statements from the respective banks' websites for the period 2015 to 2019. The banks involved in the study are:

- ABSA (formerly Barclays)

- Stanbic Bank Botswana

- Botswana Savings Bank

- First National Bank Botswana

- BancABC

- State Bank of India

- First Capital Bank

- Bank Gaborone

- Standard Chartered Bank Botswana

- Bank of Baroda

- Botswana Building Society

\subsection{Data Analysis}

Correlation analysis between each dependent variable and the independent variable was performed in order to find out their association. Using multiple regression analysis, three models were considered to achieve the objectives which include the evaluation of the financial performance of the 11 commmercial banks under study.

\subsection{First Model}

The general ROA model is:

$$
\mathrm{ROA}=\beta_{0}+\sum_{i} \beta_{i} * X_{i}+\mu_{i}
$$

where;

- $i$ ranges from 1 to 15 ,

- $\beta_{0}$ is the constant term to be determined,

- $\beta_{i}$ are the coefficients to be determined,

- $X_{i}$ is the $i^{\text {th }}$ driver of ROA,

- $\mu_{i}$ is a random error. 
Table 1 shows that there was no significant correlation between ROA and the 15 independent variables, however, there was a positive correlation between ROA and each of the independent variables except for 5 namely, CAR, A_E, IE_A, LLP_TL and NETII_TI. This indicates that ROA increases when each of these 5 variables decreases.

The ROA model is::

$$
\begin{aligned}
\mathrm{ROA}= & 0.254-1.082 * \mathrm{IE} \_\mathrm{A}+0.846 * \mathrm{II} \_\mathrm{AVG} \_\mathrm{TA}-0.021 * \mathrm{NETII} \text { _TA } \\
& -0.099 * \mathrm{CAR}-0.437 * \mathrm{LLP} \_\mathrm{TL}-0.239 * \mathrm{TL} \_\mathrm{TA}-0.421 * \mathrm{NIM}
\end{aligned}
$$

The above model shows that the major drivers of ROA for the 11 banks are IE_A, II_AVG_TA, NETII_TA, CAR, LLP_TL, TL_TA and NIM with II_AVG_TA being the largest driver with a coefficient of 0.846 as shown in Table 2 . This implies that a 1 -unit incrase in II_AVG_TA results in a 0.846 increase in ROA assuming all other variables are held constant, hence the two are positvely correlated. The smallest driver is IE_A with a coefficient of -1.082, and this implies that a 1-unit increase in IE_A results in a 1.082 decrease in ROA assuming all other variables are held constant, hence the 2 are negatively correlated. The constant of 0.254 means that in the absence of all drivers, banks in Botswana generally have an ROA of $25.4 \%$.

The $\mathrm{R}^{2}$ value in Table 3 shows that $90.8 \%$ of the variation in the dependent variable (ROA) is explained by the explanatory variables, while the adjusted $\mathrm{R}^{2}$ value shows that only $89.4 \%$ of the variation in the dependent variable (ROA) is explained by the explanatory variables, hence the two values indicate a good explanatory power of the regression model.

The significance value in Table 4 shows that the model is significant at the chosen level of significance of $5 \%$ as the significant value $=0.000<0.05$ (chosen significance level). Therefore, IE_A, II_AVG_TA, NETII_TI, CAR, LLP_TL, TL_TA and NIM have a significant impact on ROA of the 11 banks under study.

\begin{tabular}{|c|c|c|c|c|c|c|c|c|c|c|c|c|c|c|c|c|c|}
\hline & & 昰 & $\begin{array}{l}\overleftrightarrow{G} \\
\overleftrightarrow{U}\end{array}$ & 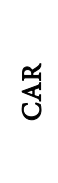 & $\stackrel{\hookrightarrow}{\leftrightarrows}$ & $\begin{array}{l}\varangle \\
\text { 凹 }\end{array}$ & 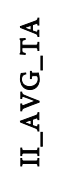 & 兒 & $\begin{array}{l}\stackrel{\rho}{G} \\
\stackrel{\hookrightarrow}{\hookrightarrow}\end{array}$ & 苗 & $\begin{array}{l}\overrightarrow{F^{\prime}} \\
\text { 岁 }\end{array}$ & 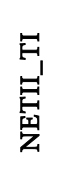 & $\begin{array}{l}\overrightarrow{\mathrm{F}^{\prime}} \\
\overrightarrow{\mathrm{z}}\end{array}$ & $\underset{Z}{\Sigma}$ & 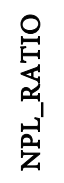 & $\begin{array}{l}\overleftrightarrow{\leftrightarrows} \\
\vec{H} \\
\vec{H}\end{array}$ & 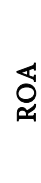 \\
\hline \multirow{3}{*}{ 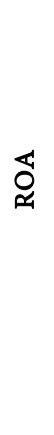 } & 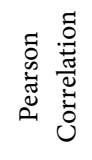 & 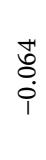 & $\begin{array}{l}0 \\
\infty \\
0 \\
0\end{array}$ & 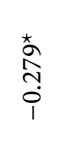 & 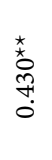 & 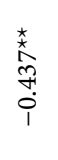 & 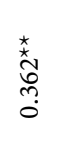 & 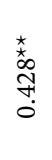 & $\stackrel{\infty}{\stackrel{\infty}{-}}$ & 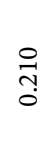 & 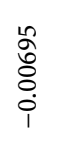 & $\begin{array}{l}\stackrel{n}{m} \\
\stackrel{0}{0} \\
1\end{array}$ & $\begin{array}{l}\stackrel{n}{\rightarrow} \\
\stackrel{0}{0}\end{array}$ & $\begin{array}{l}\stackrel{\star}{\star} \\
\stackrel{n}{n} \\
0 \\
0\end{array}$ & 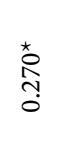 & $\begin{array}{l}0 \\
\stackrel{0}{0} \\
0 \\
0\end{array}$ & - \\
\hline & 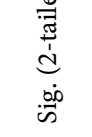 & 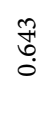 & \begin{tabular}{l}
$\infty$ \\
$\infty$ \\
\hdashline \\
0
\end{tabular} & ڤે & $\vec{\circ}$ & $\vec{\circ}$ & ôे & $\vec{\circ}$ & 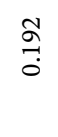 & $\underset{\stackrel{J}{I}}{\stackrel{0}{0}}$ & $\begin{array}{l}8 \\
0 \\
0\end{array}$ & 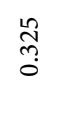 & 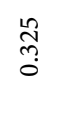 & $\begin{array}{l}\infty \\
\stackrel{0}{0} \\
0\end{array}$ & $\begin{array}{l}\stackrel{0}{0} \\
\vdots \\
0\end{array}$ & $\begin{array}{l}0 \\
\text { in } \\
0\end{array}$ & \\
\hline & $z$ & in & in & in & in & in & in & 缉 & in & in & 㓓 & in & in & in & 只 & in & in \\
\hline
\end{tabular}

Table 1. Correlation Analysis among ROA and the independent variables.

${ }^{*}$ Correlation is significant at the 0.01 level $\left(2\right.$-tailed). ${ }^{*}$ Correlation is significant at the 0.05 level (2-tailed). 
Table 2. Estimation of parametes for ROA model.

\begin{tabular}{|c|c|c|c|c|c|c|}
\hline & \multirow{2}{*}{ Model } & \multicolumn{2}{|c|}{ Unstandardized Coefficients } & \multirow{2}{*}{$\begin{array}{c}\text { Standardized Coefficients } \\
\text { Beta }\end{array}$} & \multirow[t]{2}{*}{$\mathbf{t}$} & \multirow[t]{2}{*}{ Sig. } \\
\hline & & B & Std. Error & & & \\
\hline \multirow{8}{*}{1} & (Constant) & 0.254 & 0.023 & & 10.868 & 0.000 \\
\hline & IEA & -1.082 & 0.068 & -1.012 & -15.862 & 0.000 \\
\hline & II_AVG_TA & 0.846 & 0.062 & 1.012 & 13.597 & 0.000 \\
\hline & NETII_TA & -0.021 & 0.008 & -0.184 & -2.688 & 0.010 \\
\hline & CAR & -0.099 & 0.010 & -1.078 & -10.165 & 0.000 \\
\hline & LLP_TL & -0.437 & 0.071 & -0.309 & -6.137 & 0.000 \\
\hline & TL_TA & -0.239 & 0.023 & -1.117 & -10.552 & 0.000 \\
\hline & NIM & -0.421 & 0.073 & -0.376 & -5.744 & 0.000 \\
\hline
\end{tabular}

Dependent Variable: ROA.

Table 3. Model summary.

\begin{tabular}{ccccc}
\hline Model & R & R Square & Adjusted R Square & Std. Error of the Estimate \\
\hline 1 & 0.953 & 0.908 & 0.894 & 0.00475154 \\
\hline
\end{tabular}

Table 4. ANOVA.

\begin{tabular}{|c|c|c|c|c|c|c|}
\hline & Model & Sum of Squares & $\mathrm{df}$ & Mean Square & F & Sig. \\
\hline & Regression & 0.010 & 7 & 0.001 & 65.963 & 0.000 \\
\hline \multirow[t]{2}{*}{1} & Residual & 0.001 & 47 & 0.000 & & \\
\hline & Total & 0.011 & 54 & & & \\
\hline
\end{tabular}

Dependent Variable: ROA; Predictors: (Constant), IE_A, II_AVG_TA, NETII_TI, CAR, LLP_TL, TL_TA, NIM.

\subsection{Second Model}

The general ROE model is:

$$
\mathrm{ROE}=\beta_{0}+\sum_{i} \beta_{i} * X_{i}+\mu_{i}
$$

where;

- $i$ ranges from 1 to 15 ,

- $\beta_{0}$ is the constant term to be determined,

- $\beta_{i}$ are the coefficients to be determined,

- $X_{i}$ is the $i^{\text {th }}$ driver of ROE,

- $\mu_{i}$ is a random error.

Table 5 shows that there was no significant correlation between ROE and the 15 independent variables, however, there was a positive correlation between ROE and each of the independent variables except for 5 namely, CAR, LDR, IE_A, LLP_TL and NETII_TI. This indicates that ROE increases when each of these 5 variables decreases.

The ROE model is:

$$
\begin{aligned}
\mathrm{ROE}= & 0.167-5.306 * \mathrm{IE} \_\mathrm{A}+3.644 * \mathrm{II} \_\mathrm{AVG} \text { _TA }-3.705 * \mathrm{LLP} \_\mathrm{TL} \\
& -0.318 * \mathrm{CAR}-0.011 * \mathrm{~A} \_\mathrm{E}+0.195 * \text { NII_TI }
\end{aligned}
$$


Table 5. Correlation analysis among ROE and independent variables.

\begin{tabular}{|c|c|c|c|c|c|c|c|c|c|c|c|c|c|c|c|c|c|}
\hline & & 号 & 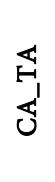 & ్․ㄴ & 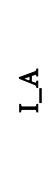 & $\begin{array}{l}\varangle \\
\text { 纴 }\end{array}$ & 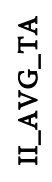 & $\begin{array}{l}\text { 岁 } \\
\text { 品 }\end{array}$ & 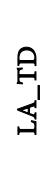 & 藏 & $\begin{array}{l}\vec{H}_{1} \\
\stackrel{H}{G}\end{array}$ & 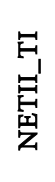 & $\begin{array}{l}\overrightarrow{F_{1}} \\
\overrightarrow{\mathrm{G}}\end{array}$ & $\underset{\mathrm{Z}}{\mathrm{Z}}$ & 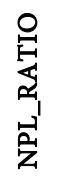 & $\begin{array}{l}\overleftrightarrow{\leftrightarrows} \\
\stackrel{G}{H}\end{array}$ & 밍 \\
\hline \multirow{3}{*}{ 떵 } & 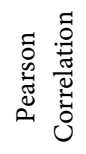 & $\begin{array}{l}\circ \\
\stackrel{0}{0} \\
0\end{array}$ & $\begin{array}{l}\stackrel{0}{\circ} \\
\stackrel{0}{0}\end{array}$ & \begin{tabular}{l} 
* \\
\multirow{2}{*}{} \\
0 \\
0 \\
1
\end{tabular} & 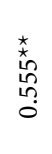 & 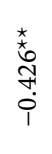 & 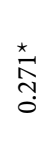 & 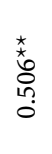 & 命 & $\begin{array}{l}\hat{\circ} \\
0 \\
i\end{array}$ & 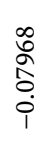 & $\begin{array}{l}\hat{n} \\
\stackrel{i}{i} \\
\stackrel{1}{1}\end{array}$ & ڤั่ & 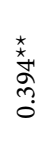 & $\begin{array}{l}10 \\
8 \\
0 \\
0 \\
0 \\
0\end{array}$ & 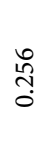 & - \\
\hline & 謧 & $\begin{array}{l}\text { శ్ } \\
\text { ô }\end{array}$ & $\begin{array}{l}\vec{n} \\
\stackrel{0}{0}\end{array}$ & $\begin{array}{l}\stackrel{2}{0} \\
\stackrel{0}{0}\end{array}$ & $\begin{array}{l}8 \\
\stackrel{0}{0} \\
0\end{array}$ & $\overrightarrow{8}$ & $\begin{array}{l}\stackrel{0}{1} \\
\stackrel{5}{0}\end{array}$ & \&̊ & $\begin{array}{l}\stackrel{\hat{\sigma}}{0} \\
0\end{array}$ & స్రి & $\begin{array}{l}\hat{B} \\
\stackrel{0}{0} \\
0\end{array}$ & $\begin{array}{l}\text { டे } \\
\text { ஜ̊ } \\
0\end{array}$ & $\begin{array}{l}0 \\
\text { L̊ } \\
0 \\
0\end{array}$ & $\begin{array}{l}\text { ô } \\
\dot{0}\end{array}$ & $\begin{array}{l}\hat{0} \\
0 \\
0\end{array}$ & 令 & \\
\hline & $z$ & in & in & in & in & in & in & in & in & in & in & in & in & in & in & in & in \\
\hline
\end{tabular}

${ }^{* *}$ Correlation is significant at the 0.01 level (2-tailed). ${ }^{*}$ Correlation is significant at the 0.05 level (2-tailed).

Table 6. Estimation of parameters for ROE model.

\begin{tabular}{|c|c|c|c|c|c|c|}
\hline & \multirow{2}{*}{ Model } & \multicolumn{2}{|c|}{ Unstandardized Coefficients } & \multirow{2}{*}{$\begin{array}{c}\text { Standardized Coefficients } \\
\text { Beta }\end{array}$} & \multirow[t]{2}{*}{$\mathrm{t}$} & \multirow[t]{2}{*}{ Sig. } \\
\hline & & B & Std. Error & & & \\
\hline \multirow{7}{*}{2} & (Constant) & 0.167 & 0.083 & & 2.014 & 0.050 \\
\hline & IEA & -5.306 & 0.663 & -0.731 & -8.006 & 0.000 \\
\hline & II_AVG_TA & 3.644 & 0.575 & 0.641 & 6.341 & 0.000 \\
\hline & LLP_TL & -3.705 & 0.759 & -0.385 & -4.882 & 0.000 \\
\hline & CAR & -0.318 & 0.066 & -0.509 & -4.816 & 0.000 \\
\hline & A_E & -0.011 & 0.002 & -0.396 & -4.319 & 0.000 \\
\hline & NII_TI & 0.195 & 0.082 & 0.258 & 2.384 & 0.021 \\
\hline
\end{tabular}

Dependent Variable: ROE.

Table 7. Model summary.

\begin{tabular}{ccccr}
\hline Model & R & R Square & Adjusted R Square & Std. Error of the Estimate \\
\hline 2 & 0.876 & 0.767 & 0.737 & 0.05078622 \\
\hline
\end{tabular}

Table 8. ANOVA.

\begin{tabular}{|c|c|c|c|c|c|c|}
\hline & Model & Sum of Squares & df & Mean Square & $\mathrm{F}$ & Sig. \\
\hline \multirow{3}{*}{2} & Regression & 0.407 & 6 & 0.068 & 26.280 & 0.000 \\
\hline & Residual & 0.124 & 48 & 0.003 & & \\
\hline & Total & 0.530 & 54 & & & \\
\hline
\end{tabular}

Dependent Variable: ROE; Predictors: (Constant), IE_A, II_AVG_TA, LLP_TL,CAR, A_E, NII_TI.

The above model shows that the major drivers of ROE for the 11 banks are IE_A, II_AVG_TA, LLP_TL, CAR, A_E and NII_TI with II_AVG_TA being the largest driver with a coefficient of 3.644 as shown in Table 6. This implies that a 1-unit incrase in II_AVG_TA results in a 3.644 increase in ROE assuming all other variables are held constant, hence the two are positvely correlated. The 
smallest driver is IE_A with a coefficient of -5.306 , and this implies that a 1-unit increase in IE_A results in a 5.306 decrease in ROE assuming all other variable are held constant, hence the 2 are negatively correlated. The constant of 0.167 means that in the absence of all drivers, banks in Botswana generally have an ROE of $16.7 \%$.

The $\mathrm{R}^{2}$ value in Table 7 shows that $76.7 \%$ of the variation in the dependent variable (ROE) is explained by the explanatory variables, while the adjusted $\mathrm{R}^{2}$ value shows that only $73.7 \%$ of the variation in the dependent variable (ROE) is explained by the explanatory variables, hence the two values indicate a good explanatory power of the regression model.

The significance value in Table 8 shows that the model is significant at the chosen level of significance of $5 \%$ as the significant value $=0.000<0.05$ (chosen significance level). Therefore, IE_A, II_AVG_TA, LLP_TL, CAR, A_E and NII_TI have a significant impact on ROE of the 11 banks under study.

\subsection{Third Model}

The general C_I model is:

$$
\mathrm{C} \_\mathrm{I}=\beta_{0}+\sum_{i} \beta_{i} * X_{i}+\mu_{i}
$$

where;

- $i$ ranges from 1 to 15 ,

- $\beta_{0}$ is the constant term to be determined,

- $\beta_{i}$ are the coefficients to be determined,

- $X_{i}$ is the $i^{\text {th }}$ driver of C_I,

- $\mu_{i}$ is a random error.

Table 9 shows that there was no significant correlation between C_I and the 15 independent variables, however, there was a negative correlation between C_I and each of the independent variables except for 3 namely, CAR, LDR and NETII_TI. This indicates that C_I increases when each of these 3 variables increases due to the positive correlation.

Table 9. Correlation Analysis among C_I and independent variables.

\begin{tabular}{|c|c|c|c|c|c|c|c|c|c|c|c|c|c|c|c|c|c|}
\hline & & 荘 & 岕 & 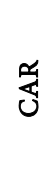 & 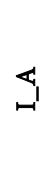 & $\begin{array}{l}\varangle \\
\text { 品 }\end{array}$ & 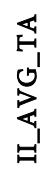 & $\begin{array}{l}\text { 舁 } \\
\text { 晋 }\end{array}$ & \begin{tabular}{l}
$\stackrel{\rho}{H}$ \\
\multirow{G}{\leftrightarrows}{}
\end{tabular} & Aี & 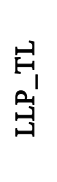 & 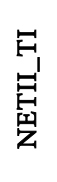 & $\begin{array}{l}\overrightarrow{F_{1}} \\
\vec{B}^{\prime}\end{array}$ & $\underset{\mathrm{Z}}{\mathrm{Z}}$ & 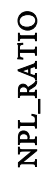 & $\begin{array}{l}\overleftrightarrow{\leftrightarrows} \\
\vec{H}^{\prime} \\
\vec{H}^{\prime}\end{array}$ & ' \\
\hline \multirow{3}{*}{ ' } & 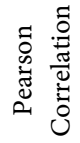 & $\begin{array}{l}\text { m } \\
\text { Oे } \\
\dot{i}\end{array}$ & 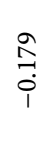 & 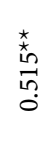 & 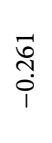 & 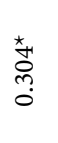 & $\begin{array}{l}\text { సे } \\
\stackrel{i}{1}\end{array}$ & \begin{tabular}{l}
0 \\
$\infty$ \\
\hdashline \\
0 \\
1
\end{tabular} & $\begin{array}{l}\text { in } \\
\stackrel{1}{0} \\
i\end{array}$ & 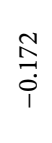 & 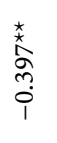 & $\begin{array}{l}8 \\
\vdots \\
0\end{array}$ & $\begin{array}{l}0 \\
\stackrel{1}{0} \\
0\end{array}$ & $\frac{\infty}{\stackrel{1}{0}}$ & 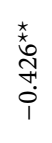 & 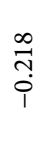 & $\neg$ \\
\hline & is & $\begin{array}{l}\stackrel{n}{n} \\
\hat{\sigma}\end{array}$ & $\underset{\sigma}{\sigma}$ & $\begin{array}{l}8 \\
\vdots \\
0\end{array}$ & $\begin{array}{l}\text { H' } \\
\text { Oे } \\
0\end{array}$ & $\begin{array}{l}\stackrel{H}{\Delta} \\
\stackrel{0}{0}\end{array}$ & ठ̊. & $\underset{\stackrel{H}{\leftrightarrows}}{\stackrel{H}{0}}$ & 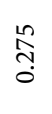 & $\underset{\vec{\nabla}}{\tilde{0}}$ & 苂 & 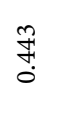 & $\underset{\mathbb{H}}{\mathbb{Z}}$ & $\stackrel{\infty}{\stackrel{\infty}{\leftrightarrows}}$ & $\overrightarrow{8}$ & $\begin{array}{l}\stackrel{\circ}{0} \\
0\end{array}$ & \\
\hline & z & in & in & in & in & in & in & in & in & in & in & 融 & in & in & in & in & in \\
\hline
\end{tabular}

${ }^{* *}$ Correlation is significant at the 0.01 level (2-tailed). ${ }^{*}$ Correlation is significant at the 0.05 level (2-tailed). 
The C_I model is:

$$
\begin{aligned}
\text { C_I }= & -4.085+2.555 * \text { CAR }-0.112 * \text { LDR }+18.918 * \text { IE_A + 4.408*TL_TA } \\
& +3.005 * \text { I_A }-7.614 * \text { II_AVG_TA }-4.992 * \text { LLP_TL + } 0.083 * \text { II_IE }
\end{aligned}
$$

The above model shows that the major drivers of C_I for the 11 banks are CAR, LDR, IE_A, TL_TA, I_A, II_AVG_TA, LLP_TL and II_IE with IE_A being the largest driver with a coefficient of 18.918 as shown in Table 10 . This implies that a 1-unit incrase in IE_A results in a 18.918 increase in C_I assuming all other variables are held constant, hence the two are positvely correlated. The smallest driver is II_AVG_TA with a coefficient of -7.614 , and this implies that a 1-unit increase in II_AVG_TA results in a 7.614 decrease in C_I assuming all other variable are held constant, hence the 2 are negatively correlated. The constant of -4.085 means that in the absence of all drivers, banks in Botswana generally have a C_I of $-408.5 \%$.

The adjusted $\mathrm{R}^{2}$ value in Table 11 shows that $84.8 \%$ of the variation in the dependent variable (C_I) is explained by the explanatory variables and hence indicates a good explanatory power of the regression model.

The $\mathrm{R}^{2}$ value in Table 11 shows that $87.0 \%$ of the variation in the dependent variable (C_I) is explained by the explanatory variables, while the adjusted $\mathrm{R}^{2}$ value shows that only $84.8 \%$ of the variation in the dependent variable (C_I) is explained by the explanatory variables, hence the two values indicate a good explanatory power of the regression model.

The significance value in Table 12 shows that the model is significant at the chosen level of significance of $5 \%$ as the significant value $=0.000<0.05$ (chosen significance level). Therefore, CAR, LDR, IE_A, TL_TA, I_A, II_AVG_TA, LLP_TL and II_IE have a significant impact on C_I of the 11 banks under study.

\begin{tabular}{|c|c|c|c|c|c|c|}
\hline & \multirow{2}{*}{ Model } & \multicolumn{2}{|c|}{ Unstandardized Coefficients } & \multirow{2}{*}{$\begin{array}{c}\text { Standardized Coefficients } \\
\text { Beta }\end{array}$} & \multirow[t]{2}{*}{$\mathbf{t}$} & \multirow[t]{2}{*}{ Sig. } \\
\hline & & B & Std. Error & & & \\
\hline \multirow{9}{*}{3} & (Constant) & -4.085 & 0.596 & & -6.857 & 0.000 \\
\hline & CAR & 2.555 & 0.239 & 1.427 & 10.704 & 0.000 \\
\hline & LDR & -0.112 & 0.039 & -0.208 & -2.856 & 0.006 \\
\hline & IE_A & 18.918 & 2.250 & 0.910 & 8.407 & 0.000 \\
\hline & TL_TA & 4.408 & 0.560 & 1.060 & 7.877 & 0.000 \\
\hline & I_A & 3.005 & 1.454 & 0.212 & 2.066 & 0.044 \\
\hline & II_AVG_TA & -7.614 & 1.255 & -0.467 & -6.065 & 0.000 \\
\hline & LLP_TL & -4.992 & 1.680 & -0.181 & -2.971 & 0.005 \\
\hline & II_IE & 0.083 & 0.029 & 0.373 & 2.892 & 0.006 \\
\hline
\end{tabular}

Table 10. Estimation of parameters.

Dependent Variable: C_I.

Table 11. Model summary.

\begin{tabular}{ccccr}
\hline Model & R & R Square & Adjusted R Square & Std. Error of the Estimate \\
\hline 3 & 0.933 & 0.870 & 0.848 & 0.11083049 \\
\hline DOI: $10.4236 /$ jmf.2021.113022 & & & & Journal of Mathematical Finance
\end{tabular}


Table 12. ANOVA.

\begin{tabular}{|c|c|c|c|c|c|c|}
\hline \multicolumn{2}{|c|}{ Model } & \multirow{2}{*}{$\begin{array}{c}\text { Sum of Squares } \\
3.787\end{array}$} & \multirow{2}{*}{$\frac{\mathrm{df}}{8}$} & \multirow{2}{*}{$\begin{array}{c}\text { Mean Square } \\
0.473\end{array}$} & \multirow{2}{*}{$\begin{array}{c}\mathrm{F} \\
38.541\end{array}$} & \multirow{2}{*}{$\begin{array}{r}\text { Sig. } \\
0.000\end{array}$} \\
\hline & Regression & & & & & \\
\hline \multirow[t]{2}{*}{3} & Residual & 0.565 & 46 & 0.012 & & \\
\hline & Total & 4.352 & 54 & & & \\
\hline
\end{tabular}

Dependent Variable: C_I; Predictors: (Constant), CAR, LDR, IE_A, TL_TA, I_A, II_AVG_TA, LLP_TL, II_IE.

\section{Discussion of the Results and Conclusions}

This study aimed at examining the financial performance of 11 banks in Botswana using ROA, ROE and C_I as the performance measures.

Firstly, the ROA was used to measure the internal-based performance of the 11 banks. ROA measures bank profitability and it provides information about management's performance in using the assets of the business to generate income. The results show that II_AVG_TA is positively correlated and is the largest driver of ROA. CAR was found to have a negative effect on financial performance, and this is not in agreement with Munangi and Sibindi (2020) [1].

Secondly, the ROE, another basic measure of bank profitability was used to study and understand the amount of a bank's income that is returned as shareholders equity. Among others, II_AVG_TA was found to be the largest driver of ROE for the 11 banks and is positively correlated to ROE as seen by Table 6.

Finally, the C_I ratio which measures how costs are changing in comparison to income was used to study and understand the productivity and efficiency of the 11 banks. The largest driver of the C_I ratio was the IE_A ratio with a coefficient of 18.918 , hence positvely correlated to C_I. TL_TA was found to be the second largest driver of the C_I ratio.

In conclusion, the largest driver for ROA and ROE was found to be the II_AVG_TA ratio, however, this ratio was the smallest driver for the C_I ratio. The largest driver for the C_I ratio was found to be IE_A ratio, but at the same time, the IE_A ratio turned out to be the smallest driver for the ROA and ROE measures. LLP_TL ratio has a negative effect on both ROA and ROE and this is in agreement with Demirhan (2013) [15]. In this study, CAR was found to have a negative effect on profitability.

This study was limited to 2015-2019 data because 2020 data was unavailable. Further research should be conducted including 2020 data as there was a significant change in the banking sector due to the COVID-19 pandemic.

\section{Conflicts of Interest}

The authors declare no conflicts of interest regarding the publication of this paper.

\section{References}

[1] Munangi, E. and Sibindi, A.B. (2020) An Empirical Analysis of the Impact of Credit Risk on the Financial Performance of South African Banks. Academy of Accounting 
and Financial Studies Journal, 24, 1-15.

[2] Mishkin, F.S. (2013) The Economics of Money, Banking and Financial Markets. Pearson, London.

[3] Ongore, V.O. (2013) Determinants of Financial Performance of Commercial Banks in Kenya. International Journal of Economics and Financial Issues, 3, 237-252.

[4] Qamruzzaman, Md. (2014) Analysis of Performance and Financial Soundness of Financial Institution (Banks): A Comparative Study. Research Journal of Finance and Accounting, 5, 169-186.

[5] Aymen, B.M.M. (2013) Impact of Capital on Financial Performance of Banks: The Case of Tunisia. Journal Banks and Bank Systems, 8, 47-54.

[6] Gabaraane, L. (2018) Role of Banks in Developing Economies and Opportunities Provided by Banks. Stanbic Bank Botswana, Gaborone.

[7] El Mehdi, F. (2018) Determinants of Banks' Profitability and Performance: An Overview. Munich Personal RePEc Archive, Munich.

[8] Bank of Botswana (2019) BOB Banking Supervision Annual Report. Bank of Botswana, Gaborone.

[9] Rawan, A. (2021) Evaluating Banks Financial Performance Using Financial Ratios: A Case Study of Kuwait Local Commercial Banks. Oradea Journal of Business and Economics, 4, 56-68. https://doi.org/10.47535/19910jbe078

[10] Nataraga, N.S., Nagaraja, R.C. and Ganesh, L. (2018) Financial Performance of Private Commercial Banks in India: Multiple Regression Analysis. Academy of Accounting and Financial Studies Journal, 22, Article No. 136.

[11] Antwi, F. (2019) Capital Adequacy, Cost-to-Income Ratio and Performance of Banks in Ghana. International Journal of Academic Research in Business and Social Sciences, 9, 168-184. https://doi.org/10.6007/IJARBSS/v9-i10/6471

[12] Nyarko-Baasi, M. (2018) Effects of Non-Performing Loans on the Profitbility of Commercial Banks-A Studdy of Some Selected Banks on the Ghana Stock Exchange. Global Journal of Management and Business Research: C Finance, 18, 39-47.

[13] Abduh, M. and Alias, A. (2014) Factors Determine Islamic Banking Performance in Malysia: A Multiple Regression Approach. Journal of Islamic Banking and Finance, 31, 44-54.

[14] Kablay, H. and Gumbo, V. (2021) Bank Distress Prediction Model for Botswana. Asian Research Journal of Mathematics, 17, 47-59. https://doi.org/10.9734/arjom/2021/v17i230273

[15] Demirhan, D. (2013) Effects of the Recent Financial Crises on the Determinants of Bank Profitability: Case of Turkish Banking Industry. Journal of Yasar University, 8, 5203-5228.

[16] European Central Bank (2010) Beyond ROE-How to Measure Bank Performance. European Central Bank, Frankfurt.

[17] Hussain, S. (2014) The Assessment of Operational Efficiency of Commercial Banks in India Using Cost to Income Ratio Approach. International Journal of Management and Business Research, 4, 225-234. 